\title{
Wprowadzenie. Badania nad efektywnością i produktywnością szkół wyższych
}

\section{Tematyka numeru}

Najnowszy numer Nauki i Szkolnictwa Wyższego poświęcony jest zagadnieniom związanym z efektywnością i produktywnością instytucji działających w sektorze edukacji ze szczególnym uwzględnieniem szkół wyższych. Problematyka dotycząca efektywności i produktywności funkcjonowania szkolnictwa wyższego jest obecna w debacie toczącej się zarówno na arenie międzynarodowej, jak i w Polsce. Presja na szkoły wyższe, aby efektywnie gospodarowały zasobami (głównie publicznymi), jest wywierana przez coraz większe gremia: przedstawicieli innych sektorów publicznych (Kwiek 2015), Ministerstwo Nauki i Szkolnictwa Wyższego oraz pozostałych interesariuszy. Bonaccorsi i Daraio (2007) ponad dziesięć lat temu stwierdzili, że posiadamy bardzo ograniczone informacje na temat „produkcji” wiedzy przez szkoły wyższe, jakie są czynniki ją determinujące i sprawdzające jej efektywność. Co się zmieniło od tego czasu, zwłaszcza biorąc pod uwagę, że obecnie badacze mają do dyspozycji coraz bardziej zaawansowane i różnorodne narzędzia pomiaru oraz bazy danych? Niewątpliwie badania nad efektywnością i produktywnością szkół wyższych są niezwykle istotne z punktu widzenia prowadzonej przez państwo polityki w stosunku do sektora szkolnictwa wyższego. Z drugiej strony podstawowe kwestie związane z samym definiowaniem efektywności i produktywności szkół wyższych, opomiarowaniem nakładów i wyników działalności prowadzonej przez jednostki oraz odpowiednim zastosowaniem metod służących do oceny efektywności i interpretacją wyników analiz budzą duże wątpliwości i wciąż napotykają trudności.

Dlatego numer otwiera tłumaczenie tekstu Jill Johnes pt. Pomiar efektywności, który został oryginalnie opublikowany jako rozdział w klasycznej pozycji: International Handbook on the Economics of Education (Johnes i Johnes 2004). W tekście 
tym autorka wyprowadza pojęcie efektywności z teorii produkcji, przyjmując, że takie podejście może zostać zastosowane do instytucji działających na rynku edukacji. Tekst może sprawiać wrażenie technicznego, sporo w nim wykresów oraz wzorów, ale wydaje się, że jest to niezbędne przy precyzyjnym definiowaniu miar efektywności wraz z założeniami, które przyjmuje się do ich wyprowadzenia, a potem interpretowania. Można powiedzieć, że jest to konieczna i podstawowa baza wiedzy dla badaczy, którzy chcą się zajmować pomiarem efektywności i produktywności sektora edukacji. Nieznajomość założeń wykorzystywanych metod albo ich niepoprawne zastosowanie może skutkować jakością wniosków, które są całkowicie nieuzasadnione albo wręcz błędne. Było to niestety udziałem części tekstów przysłanych do tego numeru Nauki i Szkolnictwa Wyższego, które z tego powodu nie mogły zostać zaakceptowane do publikacji. W dalszej kolejności autorka przybliża różne metody wykorzystywane do pomiaru efektywności i produktywności uczelni i szkół oraz przedstawia pierwsze badania empiryczne z ich użyciem. Jak zauważa Johnes, mocną stroną badań nad efektywnością wykorzystujących metody wyprowadzone z teorii produkcji jest nie tylko możliwość stworzenia na ich podstawie rankingów instytucji, ale i dostarczenie bogatego zasobu informacji, które mogą zostać wykorzystane przez zarządzających uczelniami w celu poprawy ich funkcjonowania. Ponadto autorka przewidziała, że metody pomiaru efektywności będą w przyszłości rozwijane, a to wywoła zapotrzebowanie na badania empiryczne w zakresie ich zastosowań w kontekście jednostek z sektora edukacji. Sama autorka w późniejszych pracach rozwijała badania nad efektywnością szkół wyższych, poruszając m.in. kwestie istnienia ekonomii skali i różnorodności w sektorze szkolnictwa wyższego (Johnes i Johnes 2016) czy też wpływu fuzji uniwersytetów na efektywność sektora (Papadimitriou i Johnes 2018).

Badania nad efektywnością szkół wyższych prowadzone są także przez badaczy z Polski. Łukasz Brzezicki (2018) w sporządzonym zestawieniu badań polskiego szkolnictwa wyższego prowadzonych za pomocą metod nieparametrycznych wyszczególnia w sumie 60 pozycji. Do wszystkich autorów z listy zostało wysłane zaproszenie do składania tekstów do niniejszego specjalnego numeru Nauki i Szkolnictwa Wyższego. W drugiej części numeru zaprezentowano oryginalne artykuły naukowe. Pierwszy autorstwa Andrzeja Szuwarzyńskiego pt. Ocena efektywności procesu dyplomowania na studiach pierwszego stopnia $w$ polskich publicznych uczelniach technicznych przedstawia analizę i ocenę funkcjonowania polskich uczelni technicznych, uwzględniając, wedle mojej wiedzy po raz pierwszy w badaniach tego typu dla polskich uczelni, problem rezygnacji ze studiów w trakcie pierwszego roku oraz terminowe uzyskanie dyplomów. W celu przybliżenia czytelnikom skali problemu warto przywołać statystyki podawane przez Szuwarzyńskiego, który stwierdza, że „około 40\% publicznych środków inwestowanych w stacjonarne studia pierwszego 
stopnia to raczej chybiona inwestycja" (Szuwarzyński 2018). Marnotrawstwo środków związane jest z tym, że inwestycja środków publicznych nie przynosi oczekiwanego zwrotu, bo studenci zrezygnowali ze studiów lub zwrot ten będzie odłożony w czasie w odniesieniu do studentów, którzy nie ukończyli studiów w terminie.

W kolejnym artykule autorstwa Piotra Pietrzaka i Joanny Baran, Efektywność i skuteczność ksztatcenia w publicznym szkolnictwie wyższym $w$ Polsce (Pietrzak i Baran 2018), poruszana jest kwestia nie tylko samej efektywności procesu kształcenia, rozumianej tutaj jako stosunek wyników (liczba absolwentów drugiego stopnia) do nakładów (liczba nauczycieli akademickich, liczba pracowników niebędących nauczycielami akademickimi oraz wartość rzeczowych aktywów trwałych), ale także skuteczności dydaktyki. W pomiarze skuteczności procesów kształcenia, autorzy za zmienne diagnostyczne przyjęli: względny wskaźnik zarobków absolwentów, czas poszukiwania pracy etatowej przez absolwentów oraz względny wskaźnik bezrobocia absolwentów, które pochodzą z bazy Ekonomicznych Losów Absolwentów szkół wyższych - ELA. Autorzy na podstawie przeprowadzonych analiz stwierdzili, że przy tak zdefiniowanych nakładach i wynikach działalności uczelni nie istnieje zależność między efektywnością procesu kształcenia a jego skutecznością.

Kolejny artykuł dotyczy bardziej specjalistycznej kwestii. Łukasz Brzezicki w artykule pt. Efektywność studiów Master of Business Administration (MBA) $w$ Polsce (Brzezicki 2018) zbadał efektywność 28 programów prestiżowych studiów MBA, które wedle mojej wiedzy nie były do tej pory oceniane w tego typu krajowych badaniach. W swoich analizach na temat wyników działalności studiów MBA autor zaczerpnął informacje z rankingu studiów MBA prowadzonego przez Perspekty$w y$. Stwierdza na ich podstawie, że studia tego typu charakteryzują się generalnie relatywnie niską efektywnością, a co za tym idzie, ich koszty funkcjonowania są względnie wysokie.

Natomiast w artykule mojego autorstwa pt. Efektywność szkót wyższych w Polsce na tle uczelni europejskich - analiza dla dziewiętnastu krajów przedstawiam analizę empiryczną efektywności szkół wyższych wraz z estymacją determinujących ją czynników w ujęciu międzynarodowym, porównując szkoły wyższe z Polski ze szkołami działającymi na rynku europejskim (Wolszczak-Derlacz 2018a). Wykorzystałam w tym celu metodę dwustopniową: w pierwszym kroku oszacowałam wskaźniki efektywności, a następnie zbadałam relację pomiędzy wybranymi zmiennymi a wskaźnikami efektywności. Na podstawie uzyskanych wyników wskazałam na pewne generalne mechanizmy i zależności. W szczególności na to, że uczelnie większe i starsze są bardziej efektywne, a porównując uczelnie o tej samej wielkości i roku założenia, można wyciągnąć wniosek, że te, które mają większy odsetek pracowników niebędących nauczycielami akademickim i niższy udział przychodów zewnętrznych w budżecie charakteryzują się niższą efektywnością. 
W kolejnej części czasopisma zaprezentowano wyniki badań autorstwa Jacka Lewickiego, który w artykule Nowy algorytm podziatu dotacji podstawowej dla uczelni akademickich: Pierwsze skutki zmian i wstępne wnioski porusza kwestie związane ze skutkami wprowadzenia w 2016 roku nowego algorytmu podziału dotacji podstawowej dla uczelni akademickich (Lewicki 2018). Autor pokazuje w nim, jak zmiany w składowych algorytmu wpłynęły na dystrybucję środków finansowych pomiędzy poszczególnymi uczelniami oraz jakie działania „dostosowawcze” podejmują jednostki w celu uzyskania wyższej dotacji.

W numerze publikujemy również wywiad z Benedettem Leporim (koordynatorem European Tertiary Education Register (ETER)) pt. Otwarty dostęp do statystyk uczelni powinien być czymś normalnym!, w którym poruszona została kwestia wyzwań związanych z tworzeniem publicznie dostępnej i zharmonizowanej bazy obejmującej dane na temat poszczególnych instytucji szkolnictwa wyższego z krajów europejskich: European Tertiary Education Register (ETER) oraz możliwości wykorzystania jej do porównań międzynarodowych (Wolszczak-Derlacz 2018b). Benedetto Lepori przekonuje, że ogólny dostęp do danych na poziomie indywidualnych uczelni powinien być czymś normalnym.

\section{Dyskusja uzyskanych wyników w świetle wykorzystanych danych i metod}

Artykuły naukowe zamieszczone w niniejszym numerze poświęcone były głównie zagadnieniom związanym z pomiarem efektywności i produktywności szkół wyższych. Prezentują one różne aspekty ich funkcjonowania. Na podstawie zamieszczonych analiz widać, jakie wyzwania stoją przed badaczami szkolnictwa wyższego w zakresie pomiaru efektywności jednostek. Przede wszystkim szkoły wyższe prowadzą wieloraką działalność: są powołane do kształcenia studentów, prowadzenia badań naukowych oraz współpracy z szeroko rozumianym otoczeniem. Nie wszystkie z rezultatów działalności uczelni są łatwe do zmierzenia i opomiarowania, a co za tym idzie, utrudniona jest ocena efektywności działalności uczelni w tych sferach. Część z badaczy skupia się wyłącznie na działalności związanej z kształceniem studentów (np. Szuwarzyński 2018; Pietrzak i Baran 2018), inni starają się uchwycić także wyniki działalności naukowej prowadzonej przez pracowników, np. poprzez dodanie do zbioru wyników liczby publikacji (Wolszczak-Derlacz 2018a). Autorzy świadomi są, że wskaźniki czysto ilościowe powinny być zbogacone o miary jakościowe (Szuwarzuński 2018; Brzezicki 2018). Już na podstawie tych kilku prac widać, że zbiór miar nakładów i wyników funkcjonowania szkół wyższych może być bardzo różny. Autorzy zamieszczonych w numerze prac zgodnie stwierdzają, że miary nakładów i wyników szkół 
wyższych, które przyjmują w swoich analizach, są zgodne z praktykami stosowanymi w analogicznych badaniach oraz wyznaczone także przez dostępność danych. Za nakłady przyjmuje się przede wszystkich zasoby osobowe wyrażone za pomocą liczby nauczycieli akademickich oraz pracowników niebędących nauczycielami akademickimi (Pietrzak i Baran 2018; Szuwarzyński 2018; Wolszczak-Derlacz 2018a), zasoby finansowe takie jak: wartość przychodów (Wolszczak-Derlacz 2018a), koszty (Brzezicki 2018), wartość rzeczowych aktywów trwałych (Pietrzak i Baran 2018), ale także liczbę godzin zajęć (Brzezicki 2018). Pomiar wyników działalności szkół wyższych nie jest łatwy. Pietrzak i Baran (2018) oraz niżej podpisana (Wolszczak-Derlacz 2018a) jako wyniki działalności uczelni przyjmują liczbę absolwentów, Szuwarzyński (2018) traktuje w ten sposób wskaźniki na temat ukończenia studiów w terminie i wskaźnik rezygnacji ze studiów (jako wynik niepożądany), a Brzezicki (2018) wykorzystuje w tym samym celu miejsce programu studiów w rankingu Perspektyw, w których brane są pod uwagę takie aspekty jak preferencje pracodawców czy opinie absolwentów.

Autorzy zamieszczonych prac do oceny efektywności jednostek (szkół wyższych/ programów studiów) zastosowali w głównej mierze metody nieparametryczne. W metodach tych efektywność rozumiana jest jako stosunek ważonej sumy wyników do ważonej sumy nakładów i ma ujęcie relatywne, gdzie poszczególne jednostki porównywane są do tych o najwyższej (wzorcowej) efektywności. Nieefektywność rozumiana jest jako możliwość uzyskania wyższych wyników przy danych nakładach lub tych samych wyników przy niższych nakładach. Wykorzystanie metod nieparametrycznych przez autorów omawianych tu prac nie jest zaskakująca, jeżeli weźmie się pod uwagę, że są to metody które „radzą” sobie z problemem wielu nakładów i wielu wyników - charakterystycznych dla działalności szkół wyższych. Niewątpliwą zaletą użytych metod nieparametrycznych jest to, że nie zakładają one a priori, jaka powinna być zależność pomiędzy nakładami a wynikami. Warto zauważyć, że autorzy są świadomi ograniczeń stosowanej metody, która, jak punktują jej adwersarze, jest metodą ilościową, w której można zatracić aspekt wewnętrznego funkcjonowania uczelni, a tym samym specyfikę samego sektora. Z drugiej strony należy pamiętać, że szkoły wyższe pomimo cech specyficznych nie funkcjonują w oderwaniu od ekonomicznej rzeczywistości, zatrudniają bowiem czynniki wytwórcze, dostarczając usług i produktów, nawet jeżeli są one trudne do zmierzenia.

Badania zamieszczone w niniejszym numerze Nauki i Szkolnictwa Wyższego dostarczyły szeregu nowych informacji na temat funkcjonowania szkół wyższych w Polsce, np. odnośnie skali problemu niekończenia studiów przez studentów w terminie i rezygnacji ze studiów (Szuwarzyński 2018), możliwości wykorzystania względnych wskaźników zarobków i bezrobocia absolwentów z bazy Ekonomicznych Losów 
Absolwentów (Pietrzak i Baran 2018) czy też danych z bazy ETER do porównań międzynarodowych (Wolszczak-Derlacz 2018a). Jest to niewątpliwie wartość dodana przeprowadzonych analiz.

Warto zauważyć, że w zamieszczonych w niniejszym numerze artykułach naukowych każdy z autorów poruszał kwestie związaną z utrudnionym dostępem do danych. Jak widać, problem z gromadzeniem, dostępem i przetwarzaniem danych na poziomie indywidualnych uczelni stanowi wciąż istotne wyzwanie dla badaczy szkolnictwa wyższego.

Mam nadzieję, że niniejszy numer Nauki i Szkolnictwa Wyższego przybliży większemu gronu badaczy szkolnictwa wyższego rozmaite aspekty związane z metodami pomiaru efektywności i produktywności szkół wyższych oraz spopularyzuje badania empiryczne prowadzone w tym zakresie.

Joanna Wolszczak-Derlacz

\section{Podziękowania}

Prezentowany numer pisma nie ukazałby się bez wsparcia udzielonego w ramach kierowanego przez prof. Marka Kwieka projektu Ministerstwa Nauki i Szkolnictwa Wyższego „Doskonałość naukowa: konkurencyjność, mierzalność, umiędzynarodowienie (od badań empirycznych do reform szkolnictwa wyższego) (EXCELLENCE)" (Dialog umowa: 0021/DLG/2016/10).

\section{Literatura}

Bonaccorsi A. i Daraio C. (red.) (2007). Universities and Strategic Knowledge Creation: Specialization and Performance in Europe. Cheltenham-Northampton, MA: Edward Elgar Publishing.

Brzezicki, Ł. (2018). Efektywność studiów Master of Business Administration (MBA) w Polsce. Nauka i Szkolnictwo Wyższe. 2(52): 131-146.

Brzezicki Ł. (2018). Zestawienie badań polskiego szkolnictwa wyższego prowadzonych za pomocą metody DEA i indeksu Malmquista w latach 2005-2017. https://www.researchgate. net/profile/Lukasz_Brzezicki [30.09.18].

Johnes, J. (2018). Pomiar efektywności, przeł. J. Wolszczak-Derlacz i J. Krzeski. Nauka i Szkolnictwo Wyższe. 2(52): 17-81.

Johnes G. i Johnes J. (red.) (2004). International Handbook on the Economics of Education, Cheltenham-Northampton, MA: Edward Elgar Publishing Ltd

Johnes, G., Johnes, J. (2016). Costs, efficiency, and economies of scale and scope in the English higher education sector. Oxford Review of Economic Policy. 32(4): 596-614. 
Kwiek, M. (2015). Competing for Public Resources: Higher Education and Academic Research in Europe: A Cross-Sectoral Perspective (6-24). W: J.C. Brada, W. Bienkowski i W. Kuboniwa (red.), International Perspectives on Financing Higher Education. London: Palgrave Macmillan.

Lewicki, J. (2018). Nowy algorytm podziału dotacji podstawowej dla uczelni akademickich. Pierwsze skutki zmian i wstępne wnioski. Nauka i Szkolnictwo Wyższe. 2(52): 171-187. Papadimitriou, M. i Johnes, J. (2018). Does merging improve efficiency? A study of English universities. Studies in Higher Education: 1-21.

Pietrzak, P.G. i Baran, J. (2018). Efektywność i skuteczność kształcenia w publicznym szkolnictwie wyższym w Polsce. Nauka i Szkolnictwo Wyższe. 2(52): 113-130.

Szuwarzyński, A. (2018). Ocena efektywności procesu dyplomowania na studiach pierwszego stopnia w polskich publicznych uczelniach technicznych. Nauka i Szkolnictwo Wyższe. 2(52): 85-111.

Wolszczak-Derlacz, J. (2018a). Efektywność szkół wyższych w Polsce na tle uczelni europejskich - analiza dla dziewiętnastu krajów. Nauka i Szkolnictwo Wyższe. 2(52): 147-170. Wolszczak-Derlacz J. (2018b). Otwarty dostęp do statystyk uczelni powinien być czymś normalnym! Wywiad z Benedetto Leporim, koordynatorem European Tertiary Education Register (ETER). Nauka i Szkolnictwo Wyższe. 2(52): 191-202.

CYTOWANIE: Wolszczak-Derlacz, J. (2018). Wprowadzenie: Badania nad efektywnością i produktywnością szkół wyższych. Nauka i Szkolnictwo Wyższe. 2(52): 7-13. DOI: 10.14746/nisw.2018.2.0.

JOANNA WOLSZCZAK-DERLACZ - doktor habilitowany nauk ekonomicznych, profesor nadzwyczajny Politechniki Gdańskiej, kierownik Katedry Nauk Ekonomicznych na Wydziale Zarządzania i Ekonomii PG. Prowadziła badania naukowe m.in. na Katolickim Uniwersytecie w Leuven (Belgia) pobyt w ramach stypendium Marie Curie, na Uniwersytecie w Glasgow (Wielka Brytania) - stypendium Dekaban Junior Fellowship, na Europejskim Instytucie Uniwersyteckim (European University Institute) we Florencji jako beneficjentka stypendium podoktorskiego Max Weber Fellowship oraz na Uniwersytecie Kalifornijskim w Berkeley w ramach programu „Mobilność Plus”. Jej zainteresowania naukowe skupiają się na teorii konwergencji gospodarczej, analizach produktywności i efektywności, ekonomii edukacji i rynkach pracy. Wyniki badań nad efektywnością i produktywnością szkół wyższych publikowała m.in. w Research Policy, Journal of Productivity Analysis, Scientometrics.

E-mail: jwo@zie.pg.gda.pl 